\title{
Assessment of Phage Abundance in Water Samples of Napahai Wetland by Epifluorescence Microscopy
}

\author{
S. Li, H.Y. Yu, C. Sun, J.K. Li, Y.L. Wei, X.L. Ji* \\ College of Life Science and Technology, Kunming University of Science and Technology, \\ Kunming, 650500, China
}

\begin{abstract}
Bacteriophage is abundant in various aquatic environment. Napahai is a seasonal plateau wetland located in Yunnan of China. But the reports on phage abundance of Napahai have not been seen. The object of this study was to make an accurate estimation for phage abundance of Napahai. We collected water samples at different sampling sites in December 2013 and detected the abundance by epifluorescence microscopy using SYBR green I or SYBR Gold. The results indicate that the phage abundance of water samples in Napahai wetland ranged from 1.35 to $3.54 \times 10^{9}$ virus-like particles $L^{-1}$. The dying effect of SYBR Gold is better than SYBR green I. Phage abundance of Napahai is close to that of Yangtze River and higher than the Yunnan Plateau lake, Bita Lake $\left(5 \times 10^{8}\right.$ particles $\left.L^{-1}\right)$ and largely lower than the polar lake Beaver Lake $\left(2 \times 10^{10}\right.$ particles $\left.\mathrm{L}^{-1}\right)[1]$.
\end{abstract}

Keywords-Napahai wetland; phage abundance; water samples; epifluorescene microscopy.

\section{INTRODUCTION}

With the deepening of the research on microbes, it was known that abundance of the virus has important significance to microbial ecology food ring[2]. Viruses in the natural environment, the total number of marine viruses in the ocean up to $4 \times 10^{30}$, are the most abundant organisms in marine ecosystem. There are almost $10^{23}$ virus infection host a second, and the vast majority of them are phage[3]. Phage in regulating the structure and diversity of microbial populations and involved in the formation of microbial loop have played an important role[4].

Napahai wetland is a unique type of wetlands in China. Napahai wetland is a seasonal plateau wetland located at longitude $99^{\circ} 37^{\prime} \sim 99^{\circ} 43^{\prime}$ and latitude $27^{\circ} 49^{\prime} \sim 27^{\circ} 55^{\prime}$ between Jinsha River Basin and Northwest Hengduan mountain middle section in Yunnan province with complex biogeographical environment. Its relatively isolated narrow waterway do not communicate with other wetlands, and its very fragile ecological environment, and is different from the mid-lower Yangtze lakes, northern plain lake wetlands and Ruoergai plateau wetland. Napahai wetland bearing the strong ultraviolet radiation and a large temperature difference between day and night has provided good conditions for microbial reproduction and mutation evolution[5].

At present the researches on phage abundance are mainly on planktonic virus in seawater, but researches on the phage abundance in Napahai wetland have not yet been reported. So the study on phage abundance in Napahai wetland have important significance to promote the development of microbial ecology. The climate of Napahai is divided into rainy and dry seasons. In each season, the phage abundance exists difference. In this study, we mainly assessed the phage abundance in water samples of Napahai wetland in dry season. The methods was by epifluorescence microscopy with SYBR green I or SYBR Gold. By this study, we accurately estimate the phage abundance in December of dry season 2013 in Napahai wetland and find out the appropriate counting conditions.

\section{MATERIALS AND METHODS}

\section{A. Collection and processing samples}

The climate of Napahai is divided into rainy and dry seasons, and December belongs to the dry season. In December 2013, We collected samples at longitude

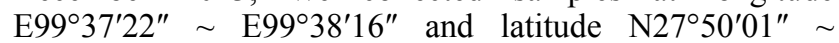
$\mathrm{N} 27^{\circ} 53^{\prime} 35^{\prime \prime}$. Based on observing of Napahai wetland, the water types were divided to raw water samples, wetland water and silt water with water content decreasing in order. We collected water samples from below $20 \mathrm{~cm}$, simultaneously detecting air temperature, water temperature, and stored the water samples in sterile brown bottle and labeled samples. The overview of water sampling sites in Napahai wetland in Dec 2013 were shown in Table I.

Filtered collected water samples with filter $(0.22 \mu \mathrm{m}$ membrane). The subsamples were immediately fixed with $0.5 \%$ glutaraldehyde (electron microscopy [EM] grade). The samples were packed in micro-tubes. Add DNAse I and RNAse A (final concentration $1 \mu \mathrm{g} / \mathrm{ml}$ ) to water samples and incubated 30 minutes. Added 25\% glutaraldehyde(final concentration $0.5 \%$, volume ratio) and fixed 15 minutes at $4{ }^{\circ} \mathrm{C}$ in the dark. Then rapidly frozen in liquid nitrogen and stored in ultra-low temperature freezer at $-80{ }^{\circ} \mathrm{C}$ for long-term preservation. Each sample was prepared triplicates in parallel. 
TABLE I WATER SAMPLING SITES IN NAPAHAI WETLAND IN DEC 2013

\begin{tabular}{cccc}
\hline Sample & $\begin{array}{c}\text { Depth } \\
(\mathrm{cm})\end{array}$ & $\begin{array}{c}\text { Air } \\
\text { pressure } \\
(\mathrm{kPa})\end{array}$ & $\begin{array}{c}\text { Altitude } \\
(\mathrm{m})\end{array}$ \\
\hline W-1 raw & $<20$ & 19.6 & 3275 \\
W-1 wetland & surface & 19.4 & 3272 \\
W-1 silt & surface & 19.5 & 3275 \\
W-2 wetland & surface & 19.5 & 3273 \\
W-3 raw & $<20$ & 19.6 & 3266 \\
\hline
\end{tabular}

B. Epifluorescence microscopy

1) Preparation equipments and reagents

A Nikon fluorescence microscope, Anodisc $\mathrm{Al}_{2} \mathrm{O}_{3}$ membrane, $0.45 \mu \mathrm{m}$ nitrocellulose membrane, $0.02 \mu \mathrm{m}$ filter, $25 \mathrm{~mm}$ coverslip, $25 \times 75 \mathrm{~mm}$ glass slides, Vacuum pump filter, a glass plate. TE buffer (pH8), SYBR Gold 10000×, SYBR Green I 10000×, anti-quencher Preparation of reagents.

Reagents must be made in freshly prepared deionized $0.02-\mu \mathrm{m}$ filtered water to prevent virus particles being introduced into the samples and causing high blanks. The TE buffer $(\mathrm{pH}=8)$ as a diluting solvent should be filtered with $0.02 \mu \mathrm{m}$ membrane. The SYBR Gold $10000 \times$ and SYBR Green I $10000 \times$ were diluted to $10 \times$, distributed into $20 \mu \mathrm{l}$ / tube, stored at $-20{ }^{\circ} \mathrm{C}$ in the dark, checked whether the precipitation before used and run out within a week. Added the anti-quencher I into anti-quencher II incubated in water bath at $30 \sim 40{ }^{\circ} \mathrm{C}$, after fully dissolved, packaging, stored at $-20{ }^{\circ} \mathrm{C}$ for three months.

\section{2) Making slides}

Production processes should be operated in low light environment, avoiding fluorescent dye failure. After the samples were removed from $-80{ }^{\circ} \mathrm{C}$, at $37{ }^{\circ} \mathrm{C}$ water bath to thaw frozen pipes. $0.45 \mu \mathrm{m}$ nitrocellulose membrane as the lining membrane was placed on a vacuum filter. Water completely wet the membrane, Place the $\mathrm{Al}_{2} \mathrm{O}_{3}$ film on lining membrane. $1 \mathrm{ml}$ of samples were added on the membrane to filter. Placed the filtered $\mathrm{Al}_{2} \mathrm{O}_{3}$ into a dark environment about $1 \mathrm{~min}$. In the Glass plate, the $10 \times$ dye was diluted with TE buffer to the final concentration $0.25 \times$ dye (each membrane about $80 \mu 10.25 \times$ dye).

The dried $\mathrm{Al}_{2} \mathrm{O}_{3}$ film was placed face up in the plates containing the dye to make full contact with $\mathrm{Al}_{2} \mathrm{O}_{3}$ film, and were stained $15 \mathrm{~min}$ in dark. To remove excess dye in the wet filter pad to maintain an $\mathrm{Al}_{2} \mathrm{O}_{3}$ film is removed under vacuum and dried in the dark until completely opaque placed on filter paper (about $5 \mathrm{~min}$ ). Added $12 \sim 15 \mu \mathrm{l}$ of anti-quenchers onto glass slides with dry $\mathrm{Al}_{2} \mathrm{O}_{3}$ film above, and dropped $20 \mu \mathrm{l}$ of anti-quencher on membrane covered with coverslip, avoiding air bubbles and marked slides. The filtered TE buffer worked as blank sample. When slides were made, it should be immediately counted or stored in $-20^{\circ} \mathrm{C}$.

\section{3) Comparing effect with different dye}

Made slides of concentrated W-1 raw water samples using $10 \times$ SYBR Gold and SYBR Green I, stored at $-20{ }^{\circ} \mathrm{C}$ for 2 days. Observe the slides and contrast effect.

\section{RESULTS}

\section{A. Determining dying and methods}

Stained samples were water samples $\mathrm{W}-1$ collected in May, 2013. The blank sample was filtered with $0.22 \mu \mathrm{m}$ membrane, and detected no existing nucleic acid. The result showed that the dying effect of SYBR Gold is better than SYBR Green I. W-1 of water samples was concentrated by hollow fiber to obtain W-1-C. Compared with the original sample, the concentrated samples have a significant concentration at $1000 \times$ Perspective (Figure 1), but the concentrated sample could have more Bacilli in the perspective, because not effectively removed bacteria.
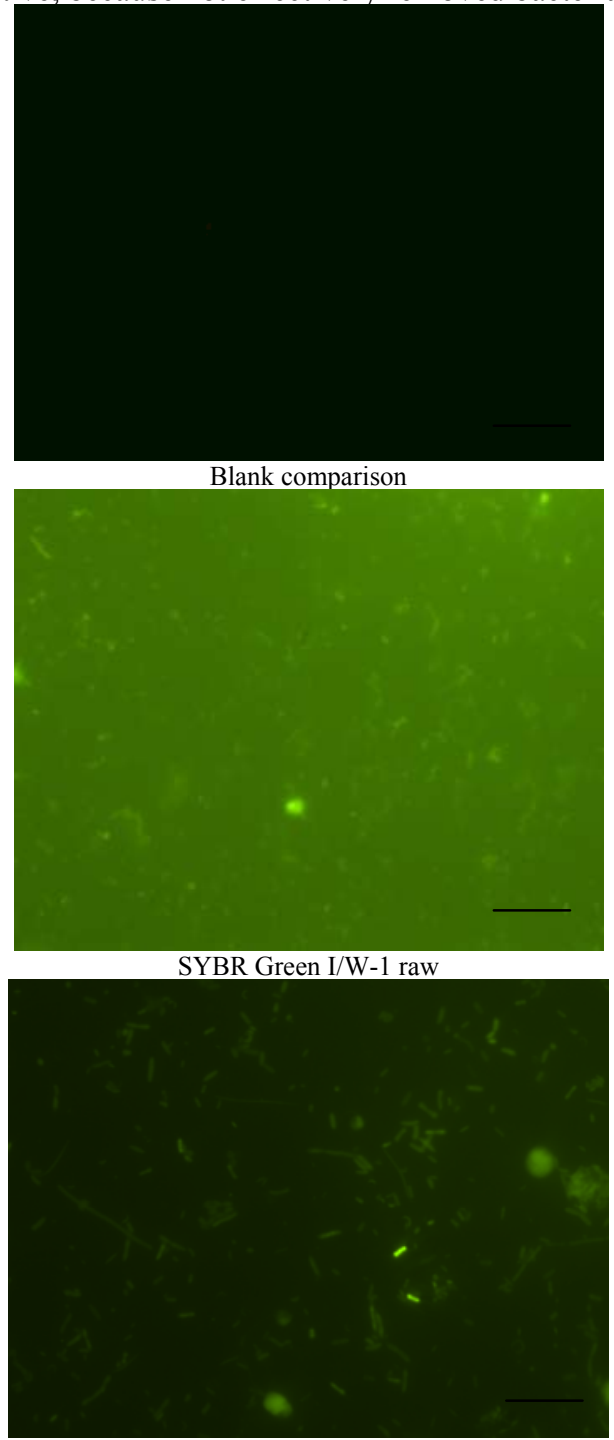

SYBR Gold / W-1-C 


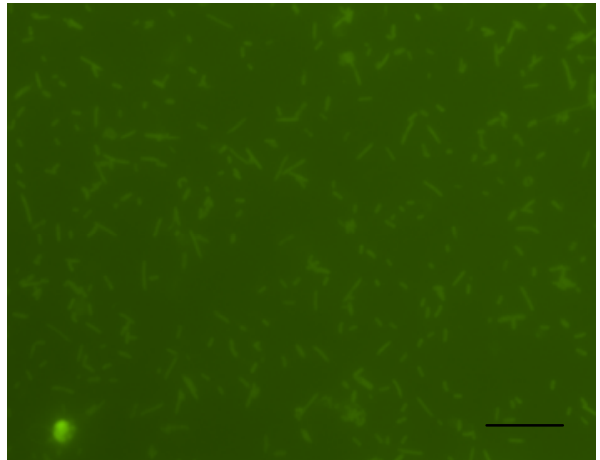

SYBR Green I/ W-1-C

*W-1 raw is original water sample

$\mathrm{W}-1 \mathrm{C}$ is concentrated samples

Figure 1. EFM images of W-1 in Dec 2013.

According to the observing of the concentrated sample of $\mathrm{W}-1$ and $\mathrm{W}-2$, it was calculated that the abundance were $2.63 \times 10^{8}$ virus-like particles $\mathrm{L}^{-1}$ and $0.89 \times 10^{8}$ virus-like particles $\mathrm{L}^{-1}$. While the abundance of original sample was $2.16 \times 10^{9}$ virus-like particles $\mathrm{L}^{-1}$, so the result showed that Napahai water samples do not need to be concentrated and diluted, SYBR Gold producer with better results, SYBR Green I fluorescence decay rapidly.

\section{B. EFM counting of phage abundance}

The original epifluorescence microscopy images of W-1 were treated to remove fog in special software, and stained phage were indicated by the arrow (Figure 2).


Removing fog of $\mathrm{W}-1$ raw samples

* ruler is $10 \mu \mathrm{m}$

Figure 2. Count phage abundance of W-1 raw samples with epifluorescence microscopy
TABLE II PHAGE ABUNDANCE OF WATER SAMPLES IN DECEMBER 2013

\begin{tabular}{cccccc}
\hline Sample & $\begin{array}{c}\mathrm{W}-1 \\
\text { raw }\end{array}$ & $\begin{array}{c}\mathrm{W}-1 \\
\text { wetland }\end{array}$ & $\mathrm{W}-2$ raw & $\begin{array}{c}\mathrm{W}-2 \\
\text { wetland }\end{array}$ & $\begin{array}{c}\mathrm{W}-3 \\
\text { raw }\end{array}$ \\
\hline Mean count & 52.8 & 37.4 & 49.4 & 30 & 78.6 \\
$\begin{array}{c}\text { Abundance } \\
10^{9} / \mathrm{L}\end{array}$ & 2.38 & 1.65 & 2.22 & 1.35 & 3.54 \\
\hline
\end{tabular}

The phage abundance of water samples collected in December 2013 were shown in Table II. Phage abundance of water samples in December 2013 ranged from 1.35 to $3.54 \times 10^{9}$ virus-like particles $\mathrm{L}^{-1}$. The abundance of mixing raw water samples were over the mud-water mixed samples.

\section{DISCUSSION}

By epifluorescence microscopy counting phage abundance with SYBR Green I and SYBR Gold, we find that the fading time of SYBR Gold was short and EFM with SYBR Gold can formed a more stable, low-background observations than SYBR Green I. The producer of SYBR Gold was still clearly after a long-time observation. Chen.et al.[6] study on SYBR Gold and SYBR Green I were not consistent with the reported findings. The study on phage abundance of samples collected in December 2013 in Napahai wetlands showed that phage abundance range of water in December 2013 ranged from 1.35 to $3.54 \times 10^{9}$ virus-like particles $\mathrm{L}^{-1}$. Phage abundance of water samples in Napahai wetland were about $10^{9} \mathrm{~L}^{-1}$ close to the abundance near the waters of the Yangtze River higher than the Northwest Yunnan Plateau lakes, Bita Lake $\left(5 \times 10^{5}\right.$ particles $\mathrm{L}^{-1}$ ), but was 10 times lower than the polar lake Beaver Lake (about $2 \times 10^{10}$ particles $\mathrm{L}^{-1}$ )[1].

May be due to lake Napa being surrounded by villages and affected by livestocks, the water had a higher degree nutrition leading the phage abundance different. Studies have shown that viral abundance of sea ice was much higher than the abundance in water [7], while in December Lake Napa was at low temperatures, the estimation of phage abundance in water samples obtained from melting water by the coast were likely lower than the actual phage abundance in lake ice. So this study on detecting phage abundance of Lake Napa wetlands collected in December may be lower than the actual. In the marine environment, about $60 \%$ of the bacterial isolates contained inducible prophage, and with the changes in seasons and temperature, nutrient levels changed [8]. The reasons for Phage abundance changes, in addition to their proliferation, was partly inducing prophage release phage. Napahai wetland with high intensity ultraviolet radiation maybe one of the factors affecting the abundance of phage.

\section{ACKNOWLEDGMENTS}

This research was supported the National Natural Science Foundation of China (31160121), and State Key Laboratory of Microbial Resources, Institute of Microbiology, Chinese Academy of Sciences (SKLMR-20110606). 


\section{REFERENCES}

[1] Säwström, C. Lisle \& J. Anesio AM et al. Bacteriophage in polar inland waters. Extremophiles, 12 (2):167-175,2008.

[2] Bettarel Y, Telesphore Sime-Ngando \& Amblard C, et a1. Viral activity in two contrasting lake ecosystems. Applied and Environmental Microbiology, 70(5):2941-2951,2004.

[3] Suttle, CA. Viruses in the sea. Nature,437(7057):356-361,2005.

[4] Yongyu, Zhang. Chunxiao, Huang. Jun,Yang, et al. Relationship between marine microorganisms and bacteriophages. Science Bulletin,56(14): 1071-1079,2011.

[5] Chengjie, Jie. Xuelian, Guo et al. The Nitrogen Mineralization in Napahai Wetland Soil of the northwest plateau of Yunnan. Acta
Ecologica Sinica,33 (24):1-6,2013.

[6] Chen F, Lu JR, Binder BJ, Liu YC, Hodson RE. Application of digital image analysis and flow cytometry to enumerate marine viruses stained with SYBR gold. Appl Environ Microbiol,67 (2): 539-545,2001.

[7] Gowing MM, Garrison DL, Gibson AH, Krupp JM, Jeffries MO, Fritsen $\mathrm{CH}$. Bacterial and viral abundance in Ross Sea summer pack ice communities. Marine Ecology Progress Series,279:3-12,2004.

[8] Cochran PK, Kellogg CA, Paul JH. Prophage induction of indigenous marine lysogenic bacteria by environmental pollutants. Marine Ecology-Progress Series, 164:125,1998. 